\title{
THE EFFECT OF INFORMATION SYSTEMS ON PERFORMANCE, PROFITABILITY, AND GROWTH OF FOOD INDUSTRIES OF GREECE
}

\author{
Vassilios Mitsos, Gregory Beligiannis \\ Department of Business Administration of Food and Agricultural Enterprises, \\ University of Patras Greece
}

DOI: 10.46609/IJSSER.2020.v05i09.004 URL: https://doi.org/10.46609/IJSSER.2020.v05i09.004

\begin{abstract}
The aim of the current research is to shed light on the effect of Information Systems (ISs) on performance, profitability, and growth of food industries in Greece. A questionnaire survey was conducted in the two hundred largest food businesses of Greece which are anonymous companies. Analysis of primary data shows that these companies are exporting and a quarter of them shows damage. Findings show that, these enterprises do not manage efficiently enough their company's balance sheet to generate profits and their fixed assets to generate sales. Moreover, most of food businesses use less than two ISs, mainly the ERP, and use them to manage only a small number of their operations. Although in the first decade of the twentieth century a revolution in the use of information systems is observed most food businesses in Greece do not invest a lot of money on ISs. Finally, firm's performance profitability and growth is independent of the size, the number and the cost of ISs. On the other hand, firms' profitability depends on the size of applied ISs. To sum up, the more ISs used by companies, the biggest the profits of the companies.
\end{abstract}

Keywords: information systems, food industries, Greece

\section{Introduction}

Nowadays companies invest millions of euros in information systems to increase their competitiveness. Information technology is considered as an essential driver for firm performance because it can increase revenue and reduce the cost of a companies. In addition, information systems investment is considered as a source of competitive advantage. Many empirical studies show the impact of information systems have on firms' performance, profitability, and growth. Most of the past researches focus on impact of e-business technology, information systems and information technology on firm's value, profitability, growth, performance, and productivity. The present research focus on information systems and software 


\section{International Journal of Social Science and Economic Research}

ISSN: $2455-8834$

Volume:05, Issue:09 "September 2020"

packages and examine their effect on firm performance, growth, and profitability in food businesses of Greece. The paper is structured as follows. The second section presents the literature review related to information systems, information technology, e-business technology, and its impact on firm performance, profitability, and growth. Based on the literature review, a research model and some hypotheses are developed. Next, we describe the sample, and explain the methodology. Finally, we analyze the results and discuss the conclusions of the study.

\section{Literature review}

Various empirical studies show the impact of information systems, information and e-business technology on value, profitability, performance, growth, and productivity of companies. We present some studies in chronological order, from 2003 until today. Firstly, we present three studies from 2000 to 2005: Dedrick J., Gurbaxani V., and Kraemer K. (2003), have a debate about whether the Information Tecnology leads in higher productivity. Studies in the 1980s find no connection between productivity and IT investment in the U.S. economy. Since then, a decade of studies at country level show that the impact of IT investment on labor productivity and economic growth of businesses is significant and positive. Ravichandran T., Chalermsak and Lertwongsatien (2005), propose a model that interrelates IS capabilities and resources, firm performance, and IT support for core competencies. The model use data collected from 129 firms in the United States. The results show that variation in firm performance is explained by the extent to which IT is used to support and fortify a firm's core competencies. The results also show that organization's ability to use IT to support its core competencies is dependent on IS functional capabilities. Finally, IS functional capabilities depends on technology, nature of human and relationship resources of the IS department. Dehning B., Richardson V., and Stratopoulos T. (2005), in their paper deal with a firm value model to assist IT researchers and managers in understanding the effects that IT investments have on a firm's value. Authors evaluate the factors that affect a firm's value. It is crucial for IT professionals to recognize the implications of IT investments on firm value. The implications of the firm value approach include forcing IT managers to think in terms of industry and company-specific effects of IT investments. Moreover, the implication of the firm value approach helps IT managers to consider: (1) both the duration and magnitude of competitive advantage due to IT investments, (2) the implications of the effect that IT investments on risk and (3) its relation to firm value. Secondly, we mention six studies from 2010 to 2015: Kharuddin S., Ashhari Z. and Nassir A. (2010), claim that information systems are widely used by many companies to improve business activities efficiency and automate existing operations. Many researches show that information system adoption increase operations and performance. Moreover, this research investigates the impact of accounting information system on firm performance of Malaysian Small and Medium sized Enterprises (SMEs). Authors use panel data to analyze firm's performance. Results reveal 


\section{International Journal of Social Science and Economic Research}

ISSN: $2455-8834$

\section{Volume:05, Issue:09 "September 2020"}

that SMEs that adopt accounting information system show significant improvement in performance in contrast to non-adopters. Mithas S., Tafti A., Bardhan I. and Goh J.M. (2012), examine whether information technology investments improve firm profitability. Using data from 1998 to 2003 for more than 400 multinational enterprises. They suggest that IT has a positive impact on profitability. Importantly, the effect of IT investments on profitability and sales is higher than that of other investments, such as R\&D and advertising. Mithas S., Ramasubbu N. and Sambamurthy V. (2012), investigate how information technology capabilities affect firm performance. This research develops a conceptual model linking IT- enabled information management capability with three essential organizational capabilities (process management capability, customer management capability and performance management capability). They claim that these three capabilities mediate the relationship between firm performance and information management capability. They find that information management capability plays an important role in developing other process management, customer management and performance management capabilities. In turn, these capabilities favorably influence financial, human resources, customer and organizational effectiveness measures of firm performance. Fuentelsaz L., Gomez J., Palomas S. (2012) explore the impact of a production technology on financial performance from the perspectives of competitive strategy theory and technology diffusion. They analyze the diffusion of the automated teller machine among Spanish banks from 1986 to 2004. Their results show that it the relative level of use and not the absolute one that drives the impact of the technology on profitability. Moreover, as the technology is growing intensively in the market, the profitability of every firm diminishes. Furthermore, in their empirical setting, this negative impact eventually leads to an aggregate negative effect on the profitability of the banks. Moriones A., Billon M. and Lera- Lopez F. (2013), investigate whether information and communication technologies (ICT) resources, have a positive effect on various dimensions of firm performance. They find that there is a positive relationship between ICT adoption and all the measures of performance. Kuzey C., Uyar A. and Delen D. (2014) investigate the impact of multinationality and other financial indicators on firm value from 1997 to 2011. Among the independent variables, multinationality was found to determine a firm's value moderately. In addition to multinationality, some other financial characteristics such as leverage, firm size, profitability and liquidity were consistently found to be affecting firm value. Lastly, we quote nine more recent studies from 2015 until today: Teekasap P. (2016), in his paper develops a mathematical model and base it on reasons from two schools of thought. The results indicate that both schools of thought are correct in different situations. In the early age, superior IT infrastructure leads to a better performance. In the long run, IT investment does not lead to a stable return. Mithas S. and Rust R. (2016), develop conjectures to understand how IT strategy and investments influence the market value and profitability of companies. They use data from 300 firms in the United States and they find that firms which emphasize on IT strategy have a higher market value than firms which give cost emphasis. On the other hand, they have 


\section{International Journal of Social Science and Economic Research}

ISSN: $2455-8834$

Volume:05, Issue:09 "September 2020"

equal profitability level. Moreover, when IT investment is low, the firm need to choose between revenue expansion and cost reduction. Contrary, when investment on IT is high, dual emphasis is given in IT strategy and IT strategy more and more pays off. Baek C.W. (2017), examine the effect of e-business adoption on firm's growth and profitability in the distribution industry. They find that the growth rate of distribution firms adopting e-business was $0.299 \%$ higher than that of the non-adopter. In the case of profitability, it was $0.04 \%$ higher than the distribution companies that did not adopt e-business. Moreover, while ERP improves both growth and profitability, Supply Chain Management (SCM) improves growth but reduces profitability. In addition, Key Management Services (KMS) improves firm's growth only and Learning Management Systems (LMS) improves only profitability. Canessa E., Morales-Flores F. and Maldifassi J. (2017) in their research argue that the impact of IT on firms' performance will differ according to the main usage of the IT system: for exploitation or exploration. Data of the research are based on Chilean organizations. They find a positive impact of using IT for exploitation on organizational performance. They also find that the use of IT for exploration has a beneficial effect on organizational change. Hazen B., Bradley R., Bell J., In J. and Byrd A. (2017) in their study, leverage competence-based theory to introduce electronic arts (EAs) strategic orientation and EAs assimilation as operational and dynamic capabilities, respectively. They collect data from 190 manufacturers, and they find that EA-based capabilities can raise performance and fortify agility of firms. Findings provide IT managers with evidence of how enterprise IT initiatives are linked to firm performance by the way of electronic arts-based capabilities. Nemlioglu I. and Mallick S. (2017) use data from UK firms from 1992 to 2014. They find that firms which focus on research and development activities jointly with better managerial practices take an advantage. Also, firms with better innovative activities and managerial practices show a positive effect. Benitez J., Chen Y., and Thompson S.H. (2018), in their research examine the evolution of the impact of ebusiness technology on operational competence and profitability. They use a dataset of 154 Spanish enterprises. Firstly, they find that e-business technology has a beneficial impact on operational competence that lessens over time. Secondly, the firm's ability to exploit a portfolio of operational capabilities has a positive impact on profitability that becomes more and more essential over time. Finally, a long discussion take place if the IT investment can stimulate firm performance. Benitz J., Llorens

J. and Braojos J. (2018) argue that information technology (IT) plays an important role in firms' opportunity exploitation and exploration. For this purpose, they use data from 203 Spanish firms. Firstly, they find that IT infrastructure provides the flexibility to explore and sense business opportunities and the foundation to build business experimentation. Secondly, IT- enabled business flexibility helps firms to exploit opportunities, to develop the operational proficiency and to increase their performance. Mouna A., Lassoued N. and Chouikha M. (2018) in their paper examine the relationship between firm profitability and state ownership in developing countries. They study 232 Tunisian from 2001 to 2013. They also find that state ownership has a positive 
International Journal of Social Science and Economic Research

ISSN: 2455-8834

Volume:05, Issue:09 "September 2020"

impact on firm profitability when it is small and negative when state ownership is high.

\section{Data and Methodology}

The purpose of this study is to examine the effect of information systems in 200 largest food companies of Greece. The study based on questionnaire took place between September $5^{\text {th }}, 2019$ and November $15^{\text {th }}$ of 2019 . This study conducted at the university of Patras in Western Greece. Data characterized as primary data which collected through a questionnaire interviews from the respondents. The level of expertise of the respondents includes owners, managers, and ordinary employees of food enterprises. The research is a qualitative research based on questionnaires. These questionnaires consisting of close answers distributed to food enterprises. The sample was 60 out of 200 food enterprises, namely 30\%, representative of the number of occupied employees and business turnover. The questionnaires were completed $10 \%$ by telephone interviews, $10 \%$ with personal interviews and the remaining $80 \%$ by e-mail. From 60 surveyed companies, 18 did reply to the questionnaire. Data collection lasted two months (from $10^{\text {th }}$ September, 2019 to $10^{\text {th }}$ November, 2019) while data statistical descriptive analysis was done using S.P.S.S. statistical software.

\section{Results}

\subsection{Business position and educational level of respondents}

\begin{tabular}{|l|l|c|c|c|c|}
\hline \multicolumn{2}{|c|}{} & \multicolumn{3}{|c|}{ Educational Level } & \multirow{2}{*}{ Total } \\
\cline { 3 - 6 } \multicolumn{2}{|c|}{} & Secondary Education & University Degree & Master & \\
\hline \multirow{3}{*}{$\begin{array}{l}\text { Business } \\
\text { Position }\end{array}$} & Owner & 4 & 0 & 0 & 4 \\
\cline { 2 - 6 } & IT Manager & 0 & 12 & 19 & 31 \\
\cline { 2 - 6 } & IT Assistant & 0 & 1 & 0 & 1 \\
\cline { 2 - 6 } & Factory Manager & 0 & 0 & 1 & 1 \\
\cline { 2 - 6 } & Financial Manager & 0 & 0 & 3 & 1 \\
\cline { 2 - 6 } & Quality Manager & 0 & 0 & 0 & 1 \\
\cline { 2 - 6 } & Staff Manager & 1 & 0 & 24 & 42 \\
\hline \multicolumn{2}{|r|}{ Total } & 5 & 13 & & \\
\hline
\end{tabular}

Table 1: Business position and educational level of respondents

Table 1 shows that the majority, namely 74\% of respondents, are IT Managers with higher education (university and master's degrees). We can also observe that $10 \%$ of the respondents are owners which have only secondary education. Moreover, 7\% of the respondents are Quality Managers that possess master's degrees. The rest $10 \%$ of the respondents are IT Assistants, Factory Managers, Financial Managers and Staff Managers. In total, human resources of the largest food businesses of Greece are highly educated. More specific 12\% have secondary 
International Journal of Social Science and Economic Research

ISSN: $2455-8834$

Volume:05, Issue:09 "September 2020"

education, $30 \%$ have university degrees and $58 \%$ possess master's degrees.

4.2 Legal form of surveyed companies and type of products they are engaged in

\begin{tabular}{|c|c|}
\hline \multirow[t]{2}{*}{ Product Type } & Legal Form \\
\hline & Société Anonyme \\
\hline Flour & 2 \\
\hline Cold Cuts & 1 \\
\hline Bakery-Pastry & 1 \\
\hline Dairy & 10 \\
\hline Olives-Olive Oil & 5 \\
\hline Sugary Products & 1 \\
\hline Pasta & 1 \\
\hline Animal Feed & 2 \\
\hline Fish Feed & 1 \\
\hline Chicken & 1 \\
\hline Meat & 3 \\
\hline Vegetables & 1 \\
\hline Honey & 1 \\
\hline Cookies & 2 \\
\hline Appetizer & 1 \\
\hline Legumes & 1 \\
\hline Sesame & 1 \\
\hline Seeds & 1 \\
\hline Fish & 4 \\
\hline Bread & 1 \\
\hline Chips \& Snacks & 1 \\
\hline Total & 42 \\
\hline
\end{tabular}

Table 2: Legal form of business as to the type of products they produce

Table 2 reveals that the largest food businesses of Greece are anonymous companies (Société Anonyme - SA). Most of food businesses, approximately 24\%, engaged with Dairy while $26 \%$ of them deal with Olives-Olive Oil, Fish and Meat. Moreover, 19\% of food businesses deal with Flour, Cookies, Chicken and Animal Feed. The rest 31\% of food businesses deal with BakeryPastry, Cold Cuts, Sugary Products, Pasta, Fish Feed, Vegetables, Honey, Appetizer, Legumes, Sesame, Seeds, Bread, Chips and Snacks. 


\subsection{Exporting companies and companies' size}

\section{EXPORTING COMPANIES}

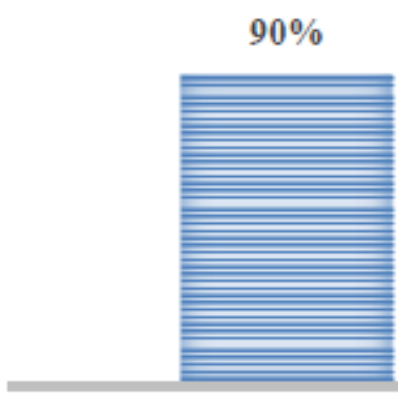

Yes
$10 \%$

No

Exports

Figure 1: Exporting companies

NUMBER OF EMPLOYEES

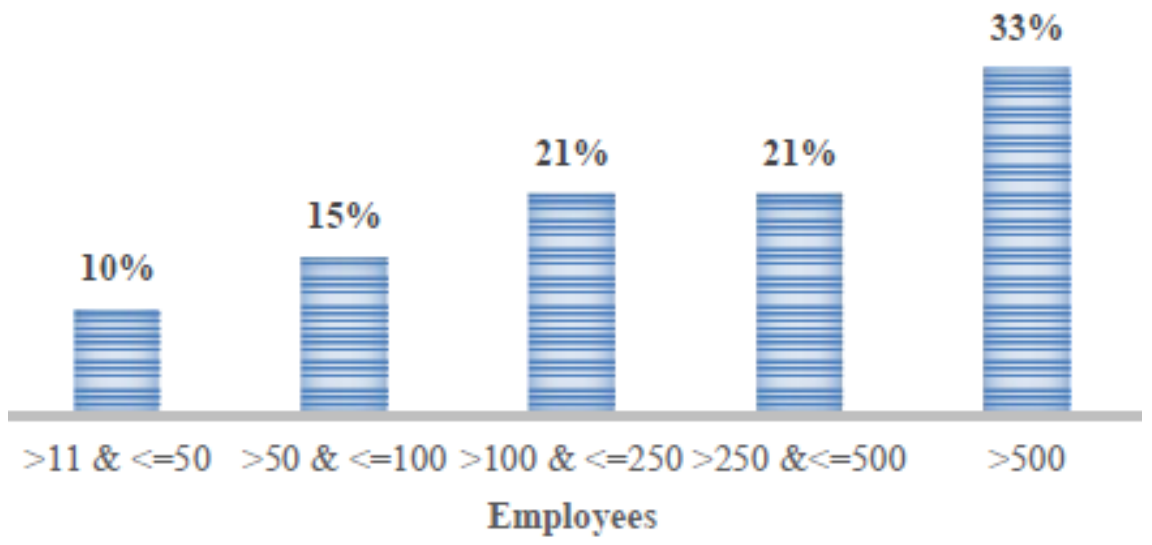

Figure 2: Companies' size according to the number of employees

According to Figure 1, most of the largest food businesses of Greece are exporting companies. More specific, approximately $90 \%$ of them export their products while the rest $10 \%$ does not. As far as the number of occupied employees is concerned, in Figure 2 we can see that most food businesses, approximately 54\%, are large enterprises with more than 250 employees. Also, $36 \%$ of food businesses are medium-sized companies with less than 250 employees and the rest $10 \%$ are small companies consist of less than 50 employees. 
International Journal of Social Science and Economic Research

ISSN: 2455-8834

Volume:05, Issue:09 "September 2020"

4.4 Firm's profits, ROA index (return on assets) and FAT index (fixed asset turnover)

FIRMS' PROFITS (MILLION EUROS)

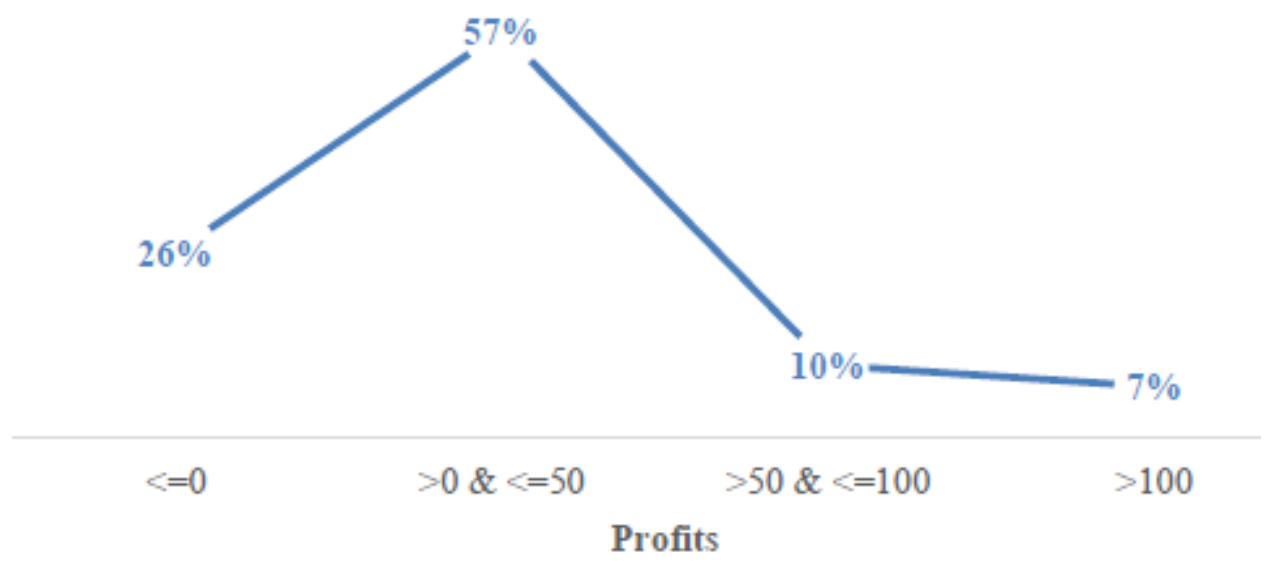

Figure 3: Firm's profits in million euros

A company's net profit is the income minus expenses related to the production, manufacture, and selling of products. Profit is the initial goal of any company. Figure 3 reveals that $26 \%$ of the largest food businesses of Greece show negative profitability while the rest $74 \%$ have a profit. Most profitable enterprises (approximately 57\%) have profits less than 50 million euros. As we can see, $10 \%$ of food businesses present profits from 50 to 100 million euros and the rest $7 \%$ have profits more than 100 million euros.

RETURN ON ASSETS, ROA

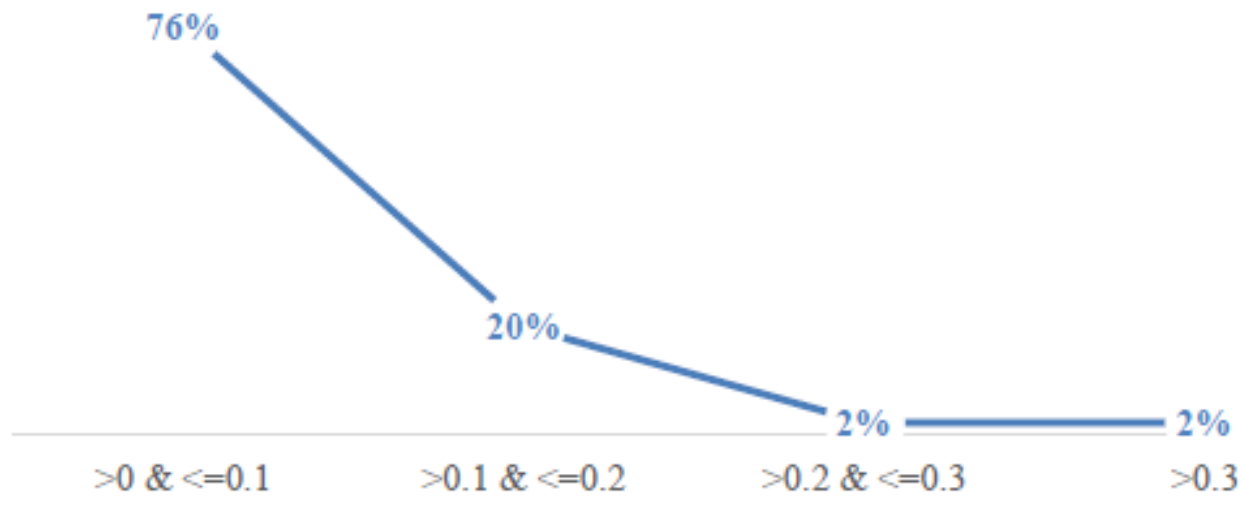

Return on Assets

Figure 4: Return on companies' assets 
Return on assets is a profitability ratio measures how efficient companies manage their assets and economic resources of the balance sheet to generate profits. ROA is presented as a percentage. The higher percentage, the more efficient a company's management considered. The formula for ROA is:

$$
\text { Rerurn on Assets }=\frac{\text { Net Income }}{\text { Total Assets }}
$$

As we can see in Figure 4, most surveyed companies have less than $10 \%$ interest rate of total invested capital. Furthermore, we observe that $20 \%$ of food enterprises have 10 to 20 percent annual return of total invested capital. Also, $2 \%$ of food businesses shows 20 to 30 percent interest rate of total invested capital. Finally, only $2 \%$ of enterprises have more than $30 \%$ annual return of total invested capital.

\section{FIXED ASSET TURNOVER RATIO (FAT)}

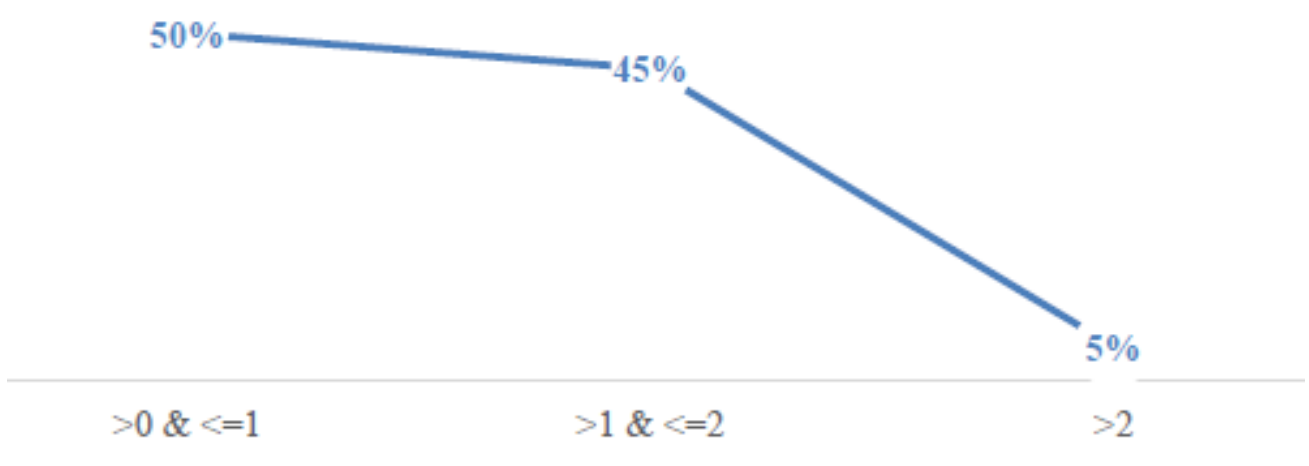

FIXED ASSET TURNOVER RATIO

Figure 5: Traffic speed of all companies' assets

The fixed asset turnover ratio (FAT) used by economists to measure operating performance. This efficiency ratio compares net sales (income) to average fixed assets of balance sheet. Moreover, measures a company's ability to generate net sales from its fixed-asset investments (e.g. facilities, equipment and property). A higher FAT ratio shows that a company use more effective its investments in fixed assets to generate sales.

$$
F A T=\frac{\text { Net Sales }}{\text { Average Fixed Assets }}
$$

where Net Sales $=$ Gross sales, less returns, and allowances, 


$$
\begin{aligned}
& \text { Average Fixed Assets }=\frac{N A B B-E n d i n g ~ B a l a n c e}{2} \text { and } \\
& N A B B=\text { Net fixed asset's beginning balance }
\end{aligned}
$$

Figure 5 shows that $50 \%$ of food companies have fixed assets turnover less than one unit. Moreover, $45 \%$ of companies have fixed assets turnover from one to two units while the rest $5 \%$ has more than two units.

4.5 Number, size and cost of information systems

NUMBER OF APPLIED IS

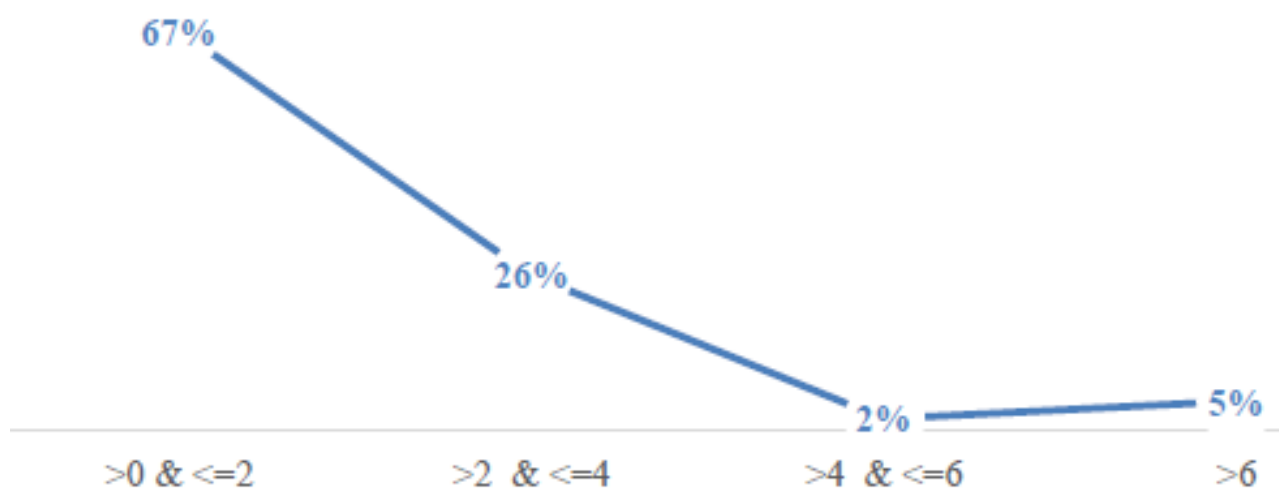

Number of IS

Figure 6: Number of applied Information Systems

Figure 6 indicates that $67 \%$ of surveyed food enterprises apply at most two information systems and software packages to manage their operations. Moreover, $26 \%$ of food businesses apply 2 to 4 information systems. Furthermore, $2 \%$ of food enterprises apply 4 to 6 software packages and information systems while the rest $5 \%$ of enterprises use more than 6 information systems or software packages. 


\section{SIZE OF IS}

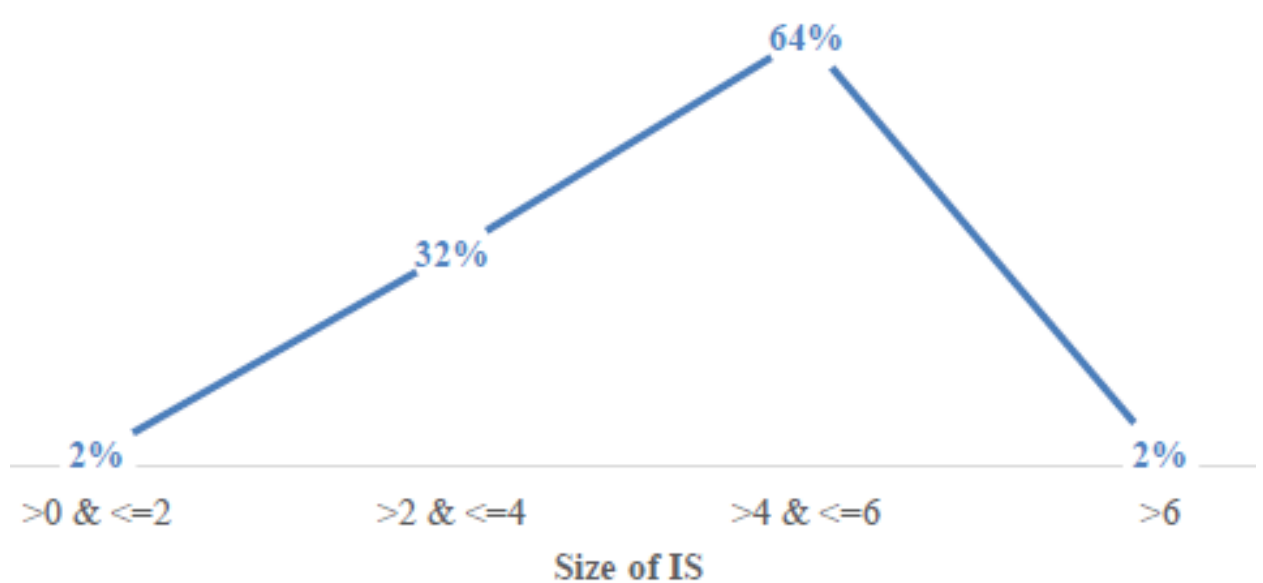

Figure 7: Size of Information Systems

Figure 7 shows that $2 \%$ of food enterprises use software packages and information systems to manage 0 to 2 of their operations. Moreover, 32\% of food businesses use software packages and information systems to manage 2 to 4 of their operations. Furthermore, most food businesses use their information systems and software packages to manage 4 to 6 of their operations. Finally, the rest $2 \%$ of food businesses use them to manage more than 6 operations.

\section{COST OF IS (MILLION EUROS)}

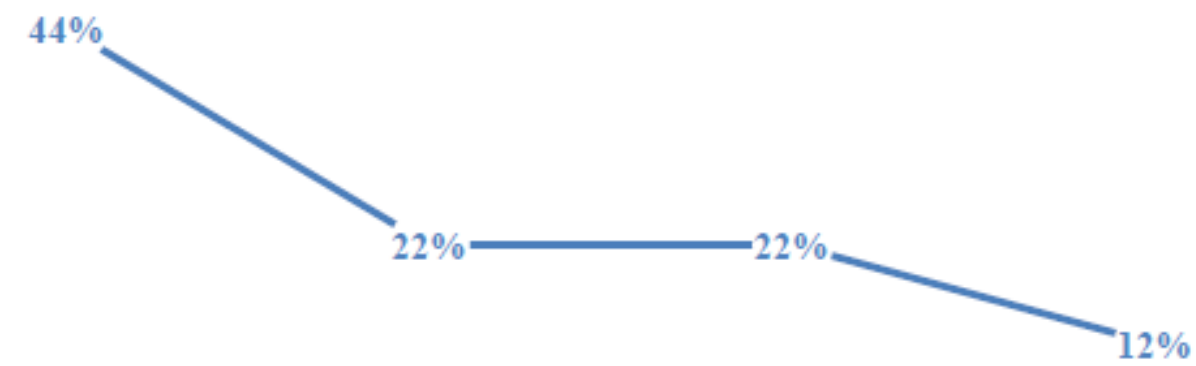

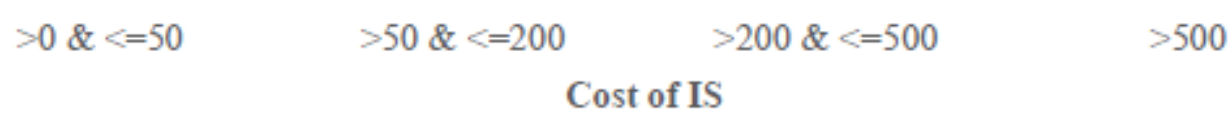

Figure 8: Cost of Information Systems

Figure 8 shows that $44 \%$ of the biggest food companies in Greece use information systems that 
International Journal of Social Science and Economic Research

ISSN: 2455-8834

Volume:05, Issue:09 "September 2020"

cost less than 50 million euros. Moreover, $22 \%$ of companies use information systems that cost 50 to 200 million euros. Furthermore, the other $22 \%$ of the food companies use information systems that cost 200 to 500 million euros. Finally, the rest $12 \%$ of companies use information systems that cost more than 500 million euros.

4.6 Year of information systems' business application

YEAR OF IS'S APPLICATION

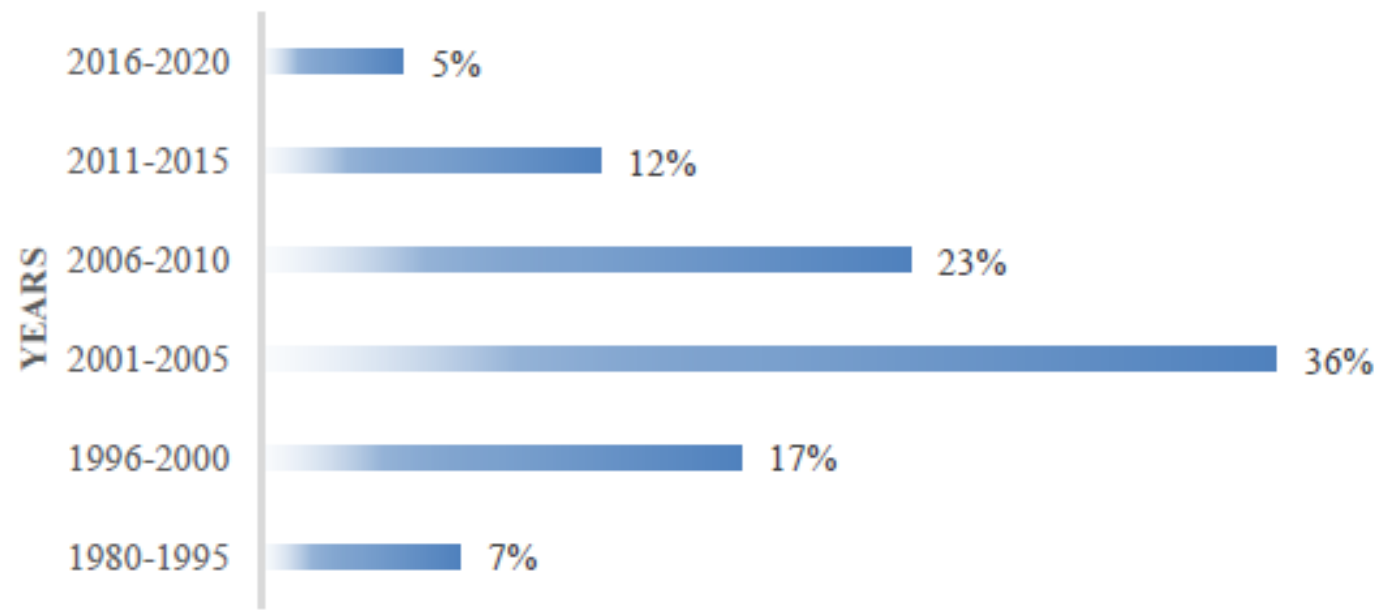

Figure 9: Year of information systems' business application

According to Figure 9, from 1980 to 1995 few large food businesses (only 7\%) in Greece start to apply information systems to manage their operations. As the years go by, from 1996 to 2000 more companies (approximately 17\%) start to adopt them. During the first five years of the millennium we have a revolution in use of information systems by large food companies (namely $36 \%$ ). Then, from 2006 to 2010 we observe a high adoption rate, but it is decreased by $13 \%$ than in the previous decade. The years 2011 to 2015 the start-up adoption rate decreased significantly in 12\%. Finally, from 2016 until today very few businesses that do not use information systems start to do so.

\section{Hypotheses development}

In this section we conduct tests of independence to correlate firms' performance, growth and profitability with the number, the size (the number of business operations that ISs cover) and the cost of applied information systems. For this purpose, we analyze our data using Pearson ChiSquare test, when less than $25 \%$ of the expected frequencies are less than 5. Otherwise, we analyze our data using Fisher's Exact test, when more than 25\% of the expected frequencies are 
International Journal of Social Science and Economic Research

ISSN: $2455-8834$

Volume:05, Issue:09 "September 2020"

less than 5. We develop and test the following hypotheses:

H0: Firm's performance is independent of the number of applied information systems H1: Firm's performance depends on the number of applied information systems Asymp. Sig: $0.608>0.05$. We accept HO.

H0: Firm's growth is independent of the number of applied information systems H1: Firm's growth depends on the number of applied information systems Asymp. Sig: $0.513>0.05$. We accept $\mathrm{H} 0$.

H0: Firm's profitability is independent of the number applied of information systems H1: Firm's profitability depends on the number of applied information systems Exact Sig: $0.197>0.05$. We accept $\mathrm{H} 0$.

H0: Firm's performance is independent of the size of applied information systems H1: Firm's performance depends on the size of applied information systems Exact. Sig: $0.059>0.05$. We accept $\mathrm{H} 0$.

H0: Firm's growth is independent of the size of applied information systems H1: Firm's growth depends on the size of applied information systems Asymp. Sig: $0.190>0.05$. We accept H0.

H0: Firm's profitability is independent of the size of applied information systems H1: Firm's profitability depends on the size of applied information systems Asymp. Sig: $0.040<0.05$. We reject $\mathrm{H} 0$.

H0: Firm's performance is independent of the cost of applied information systems H1: Firm's performance depends on the cost of applied information systems Asymp. Sig: $0.386>0.05$. We accept $\mathrm{H} 0$.

H0: Firm's growth is independent of the cost of applied information systems H1: Firm's growth depends on the cost of applied information systems Asymp. Sig: $1.000>0.05$. We accept H0. H0: Firm's profitability is independent of the cost of applied information systems H1: Firm's profitability depends on the cost of applied information systems

Exact Sig: $0.093>0.05$. We accept H0.

\begin{tabular}{|l|l|c|c|}
\hline \multicolumn{2}{|c|}{ Crosstabs } & $\begin{array}{c}\text { Pearson Chi-Square } \\
\text { Asymp. Sig. (2-sided) }\end{array}$ & $\begin{array}{c}\text { Fisher's Exact Test } \\
\text { Exact Sig. (2-sided) }\end{array}$ \\
\hline \multirow{2}{*}{$\begin{array}{l}\text { Number of } \\
\text { information } \\
\text { systems }\end{array}$} & Firms' Performance & 0.608 & - \\
\cline { 2 - 4 } & Firms' Growth & 0.513 & - \\
\cline { 2 - 4 } $\begin{array}{l}\text { Size of } \\
\text { information } \\
\text { systems }\end{array}$ & Firms' Profitability & - & 0.197 \\
\cline { 2 - 4 } & Firms' Performance & - & 0.059 \\
\cline { 2 - 4 } $\begin{array}{l}\text { Cost of } \\
\text { information } \\
\text { systems }\end{array}$ & Firm' Growth & 0.190 & - \\
\cline { 2 - 4 } & Firms' Performance & 0.040 & - \\
\cline { 2 - 4 } & Firms' Growth & 0.386 & - \\
\hline
\end{tabular}

Table 3: Chi-Square and Fisher Exact Tests (5\% significant level) 
Table 3 summarizes the results of the performed chi-square and fisher exact tests $(5 \%$ significant level). We observe that firms' performance is independent of the number, the size, and the cost of information systems. Moreover, firms' growth is independent of the number, the size, and the cost of information systems. In addition, firms' profitability is independent of the number and the cost of information systems but depends on the size of information systems.

\section{Research Model}

We find correlation between firm's profitability and the size of information systems and we conduct a simple linear regression analysis using SPSS statistical software. We formulate a model having firm's profitability as dependent variable (Y) and size of information systems (the number of business operations that ISs cover) as independent variable (X) in order to find out which is the form of the linear regression between the two variables:

$$
\mathrm{Y}=\mathrm{aX}+\mathrm{b}
$$

Y: firm's profitability

$\mathrm{X}=$ size of information systems

\begin{tabular}{|c|c|c|c|c|c|c|}
\hline \multicolumn{7}{|c|}{ Coefficients $^{\mathrm{a}}$} \\
\hline & \multirow[b]{2}{*}{ Model } & \multicolumn{2}{|c|}{ Unstandardized Coefficients } & \multirow{2}{*}{$\begin{array}{c}\text { Standardized } \\
\text { Coefficients } \\
\text { Beta } \\
\end{array}$} & \multirow[b]{2}{*}{$\mathrm{t}$} & \multirow[b]{2}{*}{ Sig. } \\
\hline & & B & Std. Error & & & \\
\hline \multirow[t]{2}{*}{1} & \begin{tabular}{|l} 
(Constant) \\
\end{tabular} & .750 & .205 & & 3.651 & .001 \\
\hline & Size of IS's & .250 & .119 & .316 & 2.108 & .041 \\
\hline
\end{tabular}

\section{$\mathrm{a}=0.25, \mathrm{~b}=0.75$}

So: $\quad \mathrm{Y}=0.25 \mathrm{X}+0.75$

Because sig (p-value) is 0.041 which is less than the significance level $(a=0.05)$, we say that variable X: (size of IS's) is significant. Keeping in mind the that the size of ISs means the number of business operations that ISs cover, we can observe that if the number of business operations covered by ISs is increased by one, the firms' profitability will grow by 0.25 million euros. To conclude, the bigger the size of information systems used is, the more the profits of the companies that use them are. 
International Journal of Social Science and Economic Research

ISSN: 2455-8834

Volume:05, Issue:09 "September 2020"

\section{Discussion and conclusions}

The purpose of this contribution was to shed light on the impact of Information Systems (ISs) on performance, profitability, and growth of food industries in Greece. To achieve this goal, a questionnaire survey was conducted in two hundred of the largest food businesses in Greece. Most of the respondents acquire university and master's degrees. Most of the bigger food companies in Greece export their products. Almost all large food companies are anonymous companies (SA). Although the most food businesses in Greece are profitable, twenty six percent show damage. The vast majority show profits less than fifty million euros, while very few have profits more than fifty and one hundred of million euros. Only seventy six percent of surveyed enterprises have less than ten percent interest rate of total invested capital. This means that these enterprises do not manage company's balance sheet efficiently enough to generate profits. Moreover, most of these companies have low fixed assets turnover ratio. This means that companies do not manage their fixed assets efficiently enough to generate sales. As far as the number of ISs are concerned, we observe that sixty five percent of big food businesses use less than two ISs, mainly the ERP. Furthermore, twenty six percent of businesses use from two to four information systems, while the minority use more of them. As far as the size of ISs are concerned, most food businesses use ISs to manage from two to six of their operations. As far as the cost of ISs is concerned, food businesses with low investments on ISs are more than those which invest on them a lot of money. Most big companies in Greece started to adopt and use ISs during the first decade of twentieth century. Finally, firm's performance, growth, and profitability are independent on the number, the size and the cost of ISs apart from the firm's profitability which depends on the size of ISs. Our research pointed out that that if the number of business operations covered by ISs is increased by one, the firms' profitability will grow by 0.25 million euros. To sum up, the bigger the size of ISs used, the more the profits of the companies that use them.

\section{References}

Baek C. (2017), The Effect of E-Business on Firm's Growth and Profitability in the Distribution Industry, Journal of Distribution Science, Vol. 15, No. 1, pp. 123-130

Benitez J., Chen Y., Thompson T., Ajamieh A. (2018), Evolution of the impact of e-business technology on operational competence and firm profitability: A panel data investigation, Information \& Management, Vol. 55, pp. 120-130

Benitez J., Lorens J., Braojos J. (2018), How information technology influence opportunity exploration and exploitation firm's capabilities, Information \& Management, Vol. 55, No. 4, pp. 508-523 


\section{International Journal of Social Science and Economic Research}

ISSN: $2455-8834$

Volume:05, Issue:09 "September 2020"

Canessa E., Morales-Flores F., Maldifassi J. (2017), The impact of IT-enhanced organizational learning on performance: evidence from Chile, Revista Facultad de Ingeniería, No. 82, pp. 60- 67

Dedrick J., Gurbaxani V., Kraemer K. (2003), Information Technology and Economic Performance: A Critical Review of the Empirical Evidence, ACM Computing Surveys, Vol. 35, No. 1 , pp. $1-28$

Dehning B., Richardson V., Stratopoulos T., (2005), Information technology investments and firm value, Information \& Management, Vol. 42, No. 7, pp. 989-1008

Fuentelsaz L., Gomez J., Palomas S. (2012), Production technologies and financial performance: The effect of uneven diffusion among competitors, Research Policy, Vol. 41, No. 2, pp: 401-413

Hazen B., Bradley R., Bell J., In Joonhwan, Byrd T. (2017), Enterprise architecture: A competence-based approach to achieving agility and firm performance, International Journal of Production Economics, Vol. 193, pp: 566-577

Kharuddin S., Ashhari Z., Nassir A. (2010), Information System and Firms' Performance: The Case of Malaysian Small Medium Enterprises, International Business Research, Vol. 3, No. 4

Kuzey C., Uyar A., Delen D. (2014), The impact of multinationality on firm value: A comparative analysis of machine learning techniques, Decision Support Systems, Vol. 59, pp: $127-142$

Mithas S., Ramasubbu N., Sambamurthy V. (2011), How information management capability influences firm performance, MIS Quarterly, Vol. 35 No. 1 pp. 237-256

Mithas S., Rust R. (2016), How information technology strategy and investments influence firm performance: Conjecture and empirical evidence, MIS Quarterly, Vol. 40, No. 1, pp. 223-245, U.S.A.

Mithas S., Tafti A., Bardhan I., Goh J. (2012), Information technology and firm profitability: Mechanisms and empirical evidence, MIS Quarterly, Vol. 36 No. 1 pp. 205-224

Moriones A., Billon M., Lopez F. (2013), Perceived performance effects of ICT in manufacturing SMEs, Industrial Management \& Data Systems, Vol. 113, No. 1, pp. 117-135

Mouna A., Lassoued N., Chouikha M. (2018), State ownership and firm profitability in emerging markets: A simultaneous equations analysis, International Journal of Public Sector Management, Vol. 31 Issue: 2, pp. 167-183 
Nemlioglu I., Mallick S. (2017), Do Managerial Practices Matter in Innovation and Firm Performance Relations? New Evidence from the UK, European Financial Management, Vol. 23, No. 5, pp: 1016-1061

Ravichandran T., Lertwongsatien C. (2005), Effect of Information Systems Resources and Capabilities on Firm Performance: A Resource-Based Perspective, Journal of Management Information Systems, Vol. 21, No. 4, pp. 237-276

Teekasap P. (2016), Information Technology Investment and Firm Performance, The 2016 Management and Innovation Technology International Conference, Thailand 